\title{
Fibronectin 1 mRNA expression correlates with advanced disease in renal cancer
}

\author{
Sandra Waalkes ${ }^{1 \dagger}$, Faranaz Atschekzei ${ }^{1 \dagger}$, Mario W Kramer ${ }^{1}$, Jörg Hennenlotter ${ }^{2}$, Gesa Vetter ${ }^{1}$, Jan U Becker ${ }^{1}$, \\ Arnulf Stenzl ${ }^{2}$, Axel S Merseburger ${ }^{1 *}$, Andres J Schrader ${ }^{3}$, Markus A Kuczyk', Jürgen Serth ${ }^{1}$
}

\begin{abstract}
Background: Fibronectin 1 (FN1) is a glycoprotein involved in cellular adhesion and migration processes. The aim of this study was to elucidate the role of FN1 in development of renal cell cancer (RCC) and to determine a prognostic relevance for optimal clinical management.

Methods: 212 renal tissue samples (109 RCC, 86 corresponding tissues from adjacent normal renal tissue and 17 oncocytomas) were collected from patients undergoing surgery for renal tumors and subjected to total RNA extraction. Detection of FN1 mRNA expression was performed using quantitative real time PCR, three endogenous controls, renal proximal tubular epithelial cells (RPTEC) as biological control and the $\triangle \triangle C$ t method for calculation of relative quantities.

Results: Mean tissue specific FN1 mRNA expression was found to be increased approximately seven fold comparing RCC and corresponding kidney control tissues $(p<0.001$; ANOVA). Furthermore, tissue specific mean FN1 expression was increased approx. 11 fold in clear cell compared to papillary RCC ( $p=9 \times 10^{-5}$; Wilcoxon rank sum test). Patients with advanced disease had higher FN1 expression when compared to organ-confined disease ( $p<0.001$; Wilcoxon rank sum test). Applying subgroup analysis we found a significantly higher FN1 mRNA expression between organ-confined and advanced disease in the papillary and not in the clear cell RCC group ( $p=0.02$ vs. $p=0.2$; Wilcoxon rank sum test). There was an increased expression in RCC compared to oncocytoma $(p=0.016 ;$ ANOVA $)$.

Conclusions: To our knowledge, this is the first study to show that FN1 mRNA expression is higher in RCC compared to normal renal tissue. FN1 mRNA expression might serve as a marker for RCC aggressiveness, indicating early systemic progression particularly for patients with papillary RCC.
\end{abstract}

\section{Background}

Renal cell carcinoma (RCC) is a common urologic tumor and accounts for about $3 \%$ of all human malignancies [1]. The annual mortality-to-incidence ratio of RCC is significantly higher compared to other urological malignancies, and its incidence has been increasing steadily in recent decades [2]. Interestingly, even organ-confined RCC of comparable stage and grade can demonstrate a significantly-varying tendency towards tumor progression and systemic spread. Correspondingly, the development of metastases can be observed in a substantial number of patients with tumors initially classified as stage $\mathrm{T} 1 \mathrm{~b}$ or

\footnotetext{
* Correspondence: merseburger.axel@mh-hannover.de

+ Contributed equally

'Department of Urology, Hannover Medical School, Germany

Full list of author information is available at the end of the article
}

T2 even more than five years after the initial treatment, hereby demonstrating the limited value of classical patients' and tumor characteristics such as tumor stage and grade to predict the clinical outcome of an individual patient.

An essential step in local disease progression and in the formation of metastases is the invasion of tumour cells into the extracellular matrix. Cell adhesion molecules and extra-cellular matrix proteins support either an increase or a decrease in the ability of tumours cells to adhere to surrounding tissue. Among the extracellular matrix proteins identified, Fibronectin $(F N)$ seems to play an important role in both inhibition and promotion of cellular attachment by interacting with different receptors. 
$F N$ is a glycoprotein that is involved in cellular adhesion and migration processes including embryogenesis, wound healing, blood coagulation, host defense, and metastasis. The molecule is widely distributed in healthy membrane, in the lamina propria, in vessel structures, nerves and smooth-muscle cell layers [3]. However, up to now the function of $F N$ is not clearly known $[4,5]$. Few studies described the potential role of $F N$ in different malignancies [5-8]. For example in hepatocellular carcinoma an overexpression of $F N$ protein was found [7]. Elevated plasma levels were detected in patients suffering from gastrointestinal and head/neck cancer [5]. In non-malignant diseases particularly in thrombosis, hemostasis, vascular disease and platelet function the definitive role of $F N$ is still unclear [9-11].

The aim of this study is to elucidate a possible role of FN1 in the development of RCC using mRNA expression analyses. 212 renal tissue samples from patients undergoing surgery for renal tumors were analysed using quantitative real time PCR. FN1 mRNA expression was significantly increased in RCC compared to corresponding normal renal tissue. Furthermore, our data suggest FN1 as marker for progressive disease especially in papillary RCC.

\section{Methods}

\section{Tissue specimens}

Tumors and corresponding tumour free tissue of 126 patients subjected to kidney surgery between 2001 and 2005 collected from the Eberhard Karls University Tuebingen were included in the present investigation. All tumors were freshly obtained from the urological department's operation room. The ethical committee of the institution approved the study. Two pathologists evaluated all specimens with respect to tumor stage, grade and histological subtypes. Tumor stages were assessed according to the UICC 2002 issue of the TNM system [12] and nuclear grading was based on the Fuhrman grading system [13]. Histological subtypes were assessed according to the consensus classification of renal cell neoplasia [14] Organ-confined RCC was defined as $\mathrm{pT} \leq$ 2 and N0/M0 and advanced as $\mathrm{pT} \geq 3$ and/or $\mathrm{N}+/ \mathrm{M}+$. The resected tissues were stored at $-80^{\circ} \mathrm{C}$. Data were collected by physicians and data managers and subsequently maintained by a relational database. Clinical and histopathological data are summarized in table 1.

\section{Primary cells}

Renal proximal tubular epithelial cells (RPTEC) were obtained from Lonza (Basel, Switzerland) and cultured according to the manufactures recommendations.

\section{Quantitative real-time PCR analysis}

Total RNA was isolated from 20 cyro sections (each $20 \mu \mathrm{m})$ using TriReagent (Ambion) according to the
Table 1 Clinical and histopathological data of patients with renal cell cancer

\begin{tabular}{|c|c|c|}
\hline Clinico-pathological parameters & $\begin{array}{l}\text { Number of } \\
\text { patients }\end{array}$ & $\%$ \\
\hline Total & 109 & 100 \\
\hline Age (mean; \pm SD) & $63 \pm 11.9$ & \\
\hline male & 70 & 64.2 \\
\hline female & 39 & 35.8 \\
\hline \multicolumn{3}{|l|}{ Side } \\
\hline left & 49 & 45 \\
\hline right & 60 & 55 \\
\hline \multicolumn{3}{|l|}{ Surgery } \\
\hline PN & 27 & 24.8 \\
\hline RN & 82 & 75.2 \\
\hline \multicolumn{3}{|l|}{ Histology } \\
\hline clear cell & 78 & 71.6 \\
\hline papillary & 22 & 20.2 \\
\hline chromophobe & 2 & 1.8 \\
\hline other/not classified & 7 & 6.4 \\
\hline \multicolumn{3}{|l|}{ Stage } \\
\hline pT1a & 34 & 31.2 \\
\hline pT1b & 30 & 27.5 \\
\hline pT2 & 5 & 4.6 \\
\hline pT3a & 13 & 11.9 \\
\hline $\mathrm{pT} 3 \mathrm{~b} / \mathrm{c}$ & 27 & 24.8 \\
\hline pT4 & 0 & 0 \\
\hline LN metastasis ${ }^{1}$ & 11 & 10.1 \\
\hline $\begin{array}{l}\text { Pulmonal/visceral } \\
\text { metastasis }^{1}\end{array}$ & 23 & 21.1 \\
\hline $\begin{array}{l}\text { Advanced/metastatic disease (pT3-4 and/or } \\
\mathrm{N} / \mathrm{M}+\text { ) }\end{array}$ & 48 & 44.0 \\
\hline \multicolumn{3}{|l|}{ Grade } \\
\hline G1 & 18 & 16.5 \\
\hline G1-2 & 15 & 13.8 \\
\hline G2 & 58 & 53.2 \\
\hline G2-3 & 7 & 6.4 \\
\hline G3 & 11 & 10.1 \\
\hline
\end{tabular}

${ }^{1}$ at time of renal surgery;

Abbreviations: $\mathrm{SD}=$ standard deviation, $\mathrm{PN}=$ partial nephrectomy, $\mathrm{RN}=$ radical nephrectomy, $\mathrm{LN}=$ lymph node.

manufacturers' instructions. Furthermore, of each tissue sample two sections were stained with hematoxylin-eosin and evaluated by a pathologist (J.U.B). Total RNA was reverse-transcribed into single-strand complementary DNA (cDNA) using the High Capacity cDNA Reverse Transcription Kit (Applied Biosystems, Foster City, CA, USA). Quantitative real time PCR analyses were performed in duplicate with an ABI 7900 Fast Sequence Detection System using TaqMan gene expression assays and universal PCR master mix according to the 
manufacturer's specifications (Applied Biosystems). The TaqMan assays were FN1 (Assay ID: Hs00365058_m1), GUSB (Hs00939627_m1), RPL13A (Hs03043885_g1) and HPRT1 (Hs99999909_m1). The human GUSB, RPL13A and HPRT1 transcripts served as endogenous controls; cDNA derived from RPTEC primary cell transcripts served as biological control. Additional no-template, no reverse transcription and blank controls were included in each run.

Data were evaluated using the SDS 2.3 Manager, dataAssist V1.0 software and the $\Delta \Delta \mathrm{Ct}$ method $[15,16]$. The three endogenous controls were combined using the dataAssist software V1.0 and "arithmetic mean" as normalization method. The method of Livak et al [16] and reference $\Delta \mathrm{Ct}$ values obtained from the biological control RPTEC were applied for calculation of $\Delta \Delta \mathrm{Ct}$ and relative quantity values, respectively. All statistics were done using the R-package 2.10.0 and Java Gui for $\mathrm{R}$ 1.7-0. For visual comparison of univariate data we used bean plots as a combination of one-dimensional scatter plots and density plots were generated using the bean plot package for $\mathrm{R}$ statistical software [17]. In all tests, $\mathrm{p}<0.05$ was considered to indicate significance.

\section{Results}

\section{FN1 mRNA expression in normal renal tissues, RCC and oncocytomas}

In order to examine the mRNA expression of FN1 in RCC, 109 tumour RNA samples and corresponding histopathological normal renal tissue of 86 of these patients were analysed using quantitative real time PCR. Furthermore, 17 tissue samples of oncocytomas were examined. Expression of FN1 was observed in all analysed samples. Mean tissue specific FN1 mRNA expression was found to be increased approximately seven fold comparing RCC and corresponding kidney control tissues ( $\mathrm{p}<0.001$; ANOVA). There was no significant difference in FN1 expression between normal renal tissue and oncocytoma. However, there was an increased expression in RCC compared to oncocytoma ( $\mathrm{p}=0.016$; ANOVA; figure 1, table 2).

\section{Clinical observations}

We investigated if any correlations of interest could be seen between the expression of $F N 1$ and clinical parameters (table 1). The mean age of the cohort was 63 years $(S D \pm 11.9)$. Seventy patients were men (64.2\%) and 39 patients were women (35.8\%). Seventy-eight patients presented with clear cell RCC, 22 patients with papillary RCCs, and two patients with chromophobe RCC and seven patients with unclassified histology.

We found a significant difference in FN1 mRNA expression between clear cell RCC and papillary RCC. The tissue specific mean FN1 expression was increased approx. 11 fold in clear cell RCC compared to papillary RCC ( $=9 \times 10^{-5}$; Wilcoxon rank sum test; figure 2$)$.

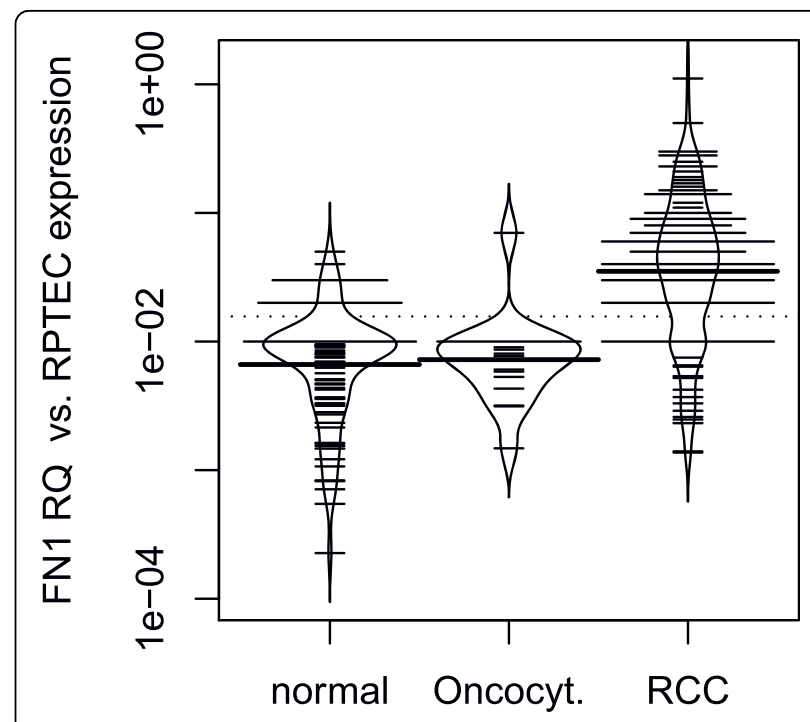

Figure 1 Bean plot analysis of relative $F N 1$ mRNA expression in normal renal tissue, oncocytoma and RCC. Bean plots represent an alternative to boxplots. The individual observations are shown as small lines in a one-dimensional scatter plot, the estimated density of the distributions is visible and the average is shown. Mean tissue specific FN1 mRNA expression was increased approx. 7 fold in RCC compared to corresponding normal renal tissue $(p<0.001)$ and oncocytoma ( $p=0.016$ ). There was no significant difference in FN1 expression between normal renal tissue and oncocytoma. Abbreviations: FN1RQ = Relative quantity of FN1 mRNA expression analysis using RPTEC primary cells as a biological calibrator; normal = normal renal tissue; Oncocyt = oncocytoma.

No significant correlation was observed for histological grading, TNM group stage, lymph node metastasis and the presence of distant metastases (Spearman R nonparametric correlation analysis).

Furthermore, we compared FN1 mRNA expression between patients with organ-confined $\mathrm{RCC}$ ( $\mathrm{pT} \leq 2$ and $\mathrm{N} 0 / \mathrm{M} 0)$ and advanced disease ( $\mathrm{pT} \geq 3$ and/or $\mathrm{N}+/ \mathrm{M}+)$. Both, organ-confined and advanced disease showed significantly higher levels of FN1 mRNA expression compared to normal renal tissues $\left(\mathrm{p}=0.022\right.$ and $\mathrm{p}<1 \times 10^{-7}$ respectively; ANOVA; figure 3). Patients with advanced disease had higher FN1 expression when compared to organ-confined disease ( $\mathrm{p}<0.001$; Wilcoxon rank sum test; figure 3). We then divided the cohort in two groups, clear cell RCC and papillary RCC. Interestingly,

Table 2 FN1 mRNA expression in normal renal tissue, RCC and oncocytoma

\begin{tabular}{lcc}
\hline Tissue & Number of tissues & FN1RQ \\
\hline Normal & 86 & 0.0118 \\
\hline RCC & 109 & 0.0821 \\
\hline Oncocytoma & 17 & 0.0117 \\
\hline Total & 212 & \\
\hline
\end{tabular}

Abbreviations: FN1RQ = Relative quantity of FN1 mRNA expression. 


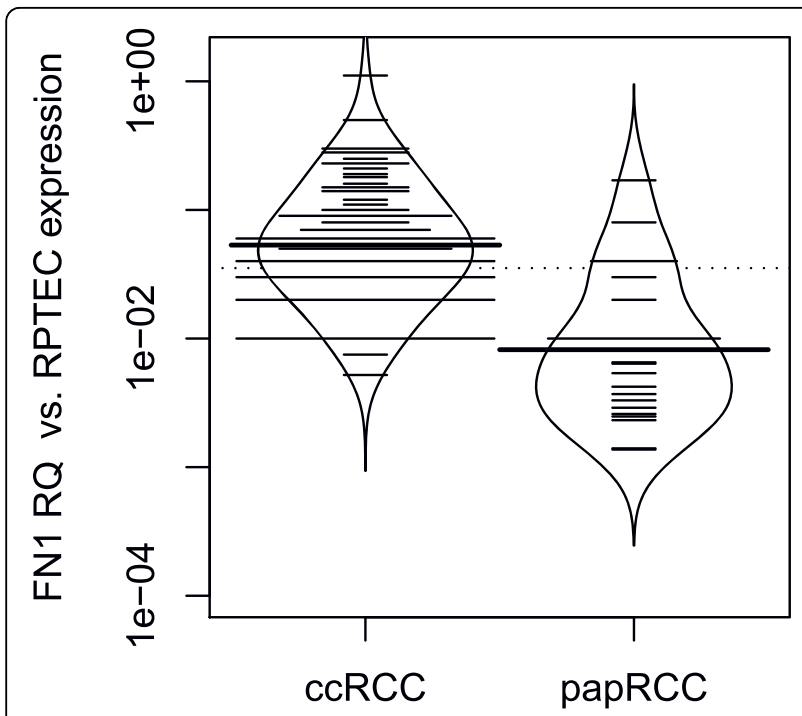

Figure 2 FN1 mRNA expression in clear cell RCC and papillary RCC. Mean tissue specific FN1 expression was increased approx. 11 fold in clear cell RCC compared to papillary RCC $(p<0.001)$. Abbreviations: FN1RQ = Relative quantity of FN1 mRNA expression analysis using RPTEC primary cells as a biological calibrator; $C C R C C=$ clear cell RCC; pRCC = papillary RCC.

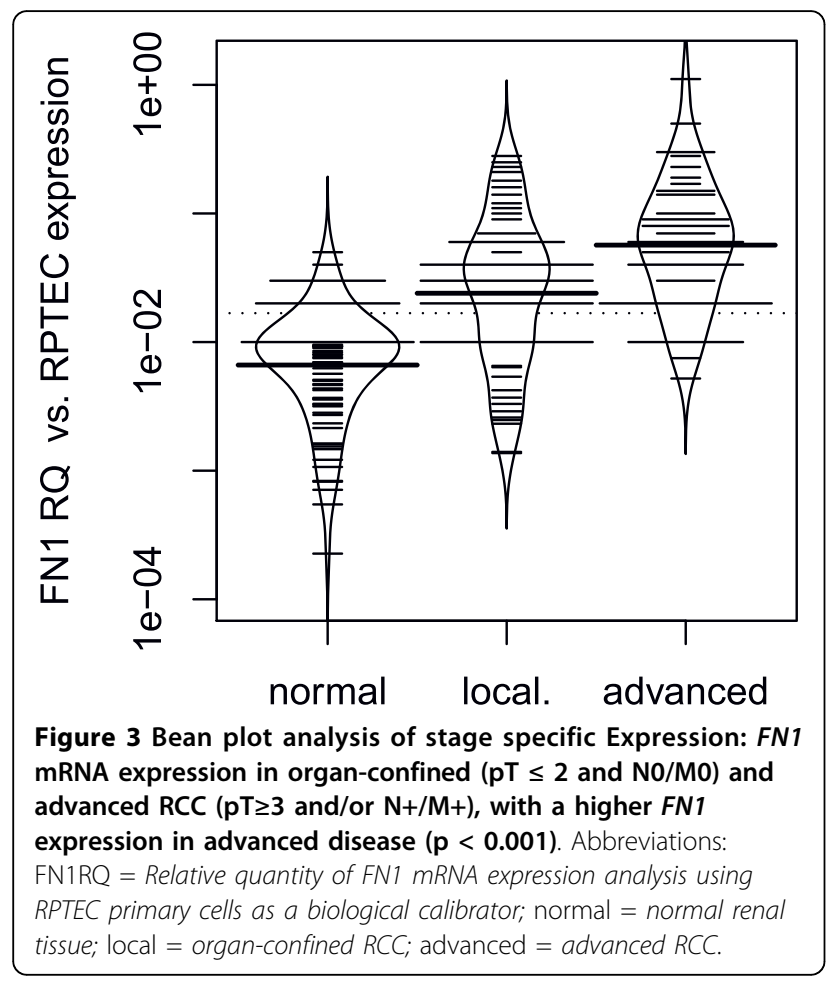

when applying subgroup analysis we found a significantly higher FN1 mRNA expression between organconfined and advanced disease in the papillary RCC and not in the clear cell RCC group ( $\mathrm{p}=0.02$ vs. $\mathrm{p}=0.2$; Wilcoxon rank sum test, figures 4 and 5 ).

\section{Discussion}

FN1 mRNA expression and its relationship to clinicopathological parameters in RCC has not yet been investigated. Functional studies have shown that $F N$ and its receptors are important in mediating cell adhesion, migration, signal transduction and possibly in prevention of apoptosis [18]. It is a component of the extracellular matrix, and cells adhere to $F N$ via the integrin transmembrane receptors. Either up-regulation or down-regulation [19-21] of $F N$ has been reported in several human cancers. The ability to promote epithelial cell migration and suppression of apoptosis, suggest that $F N$ overexpression promote various tumors types [22,23].

In the present study, a significantly increased expression of FN1 mRNA in RCC compared to normal renal tissue and oncocytoma has been shown. Both organconfined ( $\mathrm{pT} \leq 2$ and N0/M0) and advanced disease ( $\mathrm{pT} \geq 3$ and/or $\mathrm{N}+/ \mathrm{M}+$ ) showed significant higher levels of FN1 mRNA expression compared to normal renal tissue. Moreover, patients with advanced disease had higher FN1 expression when compared to organ-confined disease. This supports the hypothesis that FN contributes to renal carcinogenesis and/or RCC progression.

There have been previous functional studies suggesting $F N$ as a candidate marker for aggressive RCC. The first studies focusing on different RCC cell lines showed altered $F N$ secretion and the possibility to influence mobility and invasiveness of these malignant cells [24-26].

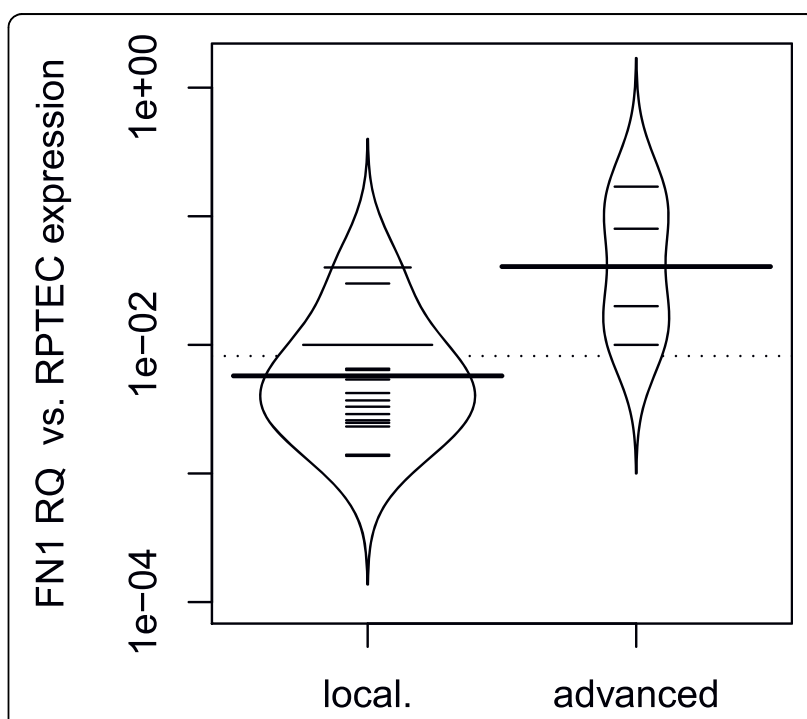

Figure 4 Progression specific Expression in papillary RCC: higher FN1 mRNA in advanced ( $\mathrm{pT} \geq 3$ and/or $\mathrm{N}+/ \mathrm{M}+$ ) compared to organ-confined ( $\mathrm{pT} \leq 2$ and N0/M0) RCC ( $p=$ 0.017). Abbreviations: $F N 1 R Q=$ Relative quantity of FN1 mRNA expression analysis using RPTEC primary cells as a biological calibrator; local = organ-confined RCC; advanced = advanced $R C C$. 


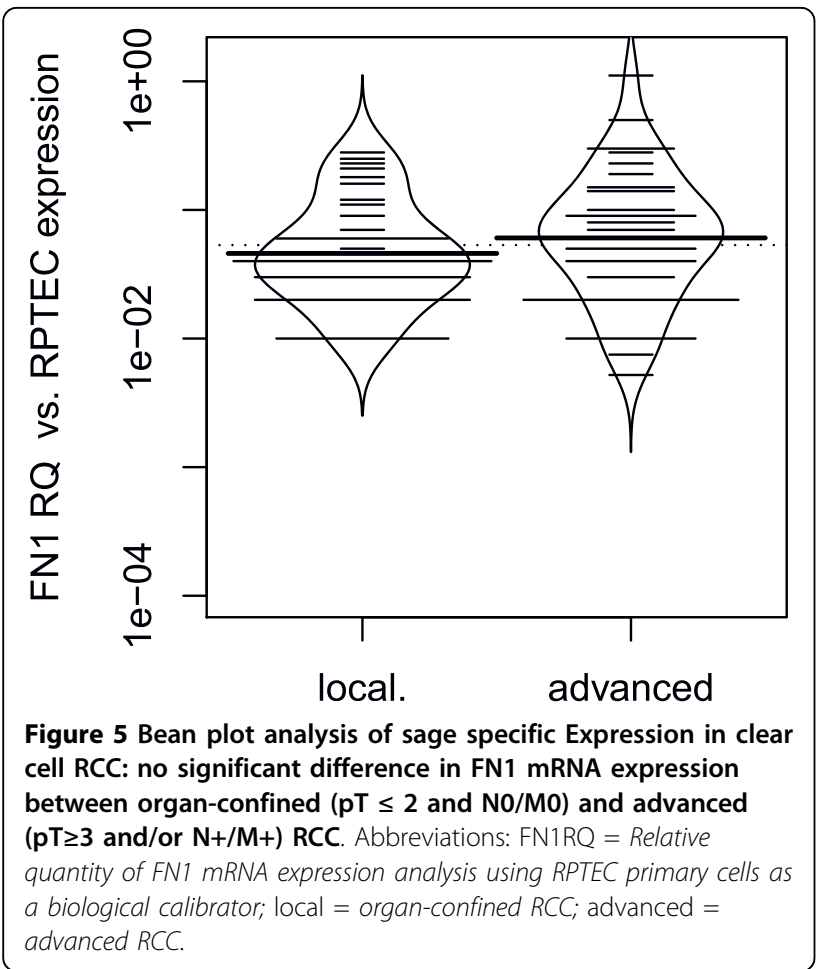

A further interesting finding in our study was a significant increase in FN1 mRNA expression in clear cell RCC compared to papillary RCC. Our results generally suggest that an increased FN1 expression is correlated to a more progressive disease in RCC. Moreover, higher FN1 expression in clear cell RCC as compared to papillary RCC support the common belief that papillary tumors are less aggressive [27]. On the other hand current data indicates that once papillary RCC has spread, it is associated with a poor survival and a higher risk of resistance to systemic therapy compared to clear cell RCC [28]. This statement is supported by the fact that we found a significant higher FN1 mRNA expression between organ-confined and advanced disease in papillary RCC but not for clear cell RCC. Papillary RCC can be sub classified into types 1 and 2 as well as into less and more aggressive tumors. FN1 might be used to differentiate between papillary RCC with less or more aggressive potential.

\section{Conclusion}

To our knowledge, this is the first study to show that FN1 mRNA expression is significantly higher in RCC compared to normal renal tissue and oncocytoma. FN1 mRNA expression might serve as a marker for RCC aggressiveness, indicating early systemic progression particularly for patients with papillary RCC. Therefore, our data on FN1 encourages further investigations to enlighten the future role of $F N 1$ in RCC.

\section{Author details}

'Department of Urology, Hannover Medical School, Germany. ²Department of Urology, Eberhard Karls University Tuebingen, Germany. ${ }^{3}$ Department of Urology, Ulm University Medical School, Ulm, Germany.

Received: 17 May 2010 Accepted: 22 September 2010

Published: 22 September 2010

\section{References}

1. Schrader AJ, Rustemeier J, Rustemeier JC, Timmesfeld N, Varga Z, Hegele A, Olbert PJ, Hofmann R: Overweight is associated with improved cancerspecific survival in patients with organ-confined renal cell carcinoma. J Cancer Res Clin Oncol 2009, 135:1693-1699.

2. Schrader AJ, Sevinc S, Olbert PJ, Hegele A, Varga Z, Hofmann R: [Genderspecific characteristics and survival of renal cell carcinoma]. Urologe A 2008, 47(1182):1184-1186.

3. Wilson CB, Leopard J, Cheresh DA, Nakamura RM: Extracellular matrix and integrin composition of the normal bladder wall. World J Urol 1996, 14(Suppl 1):S30-37.

4. Akiyama SK, Olden K, Yamada KM: Fibronectin and integrins in invasion and metastasis. Cancer Metastasis Rev 1995, 14:173-189.

5. Warawdekar UM, Zingde SM, lyer KS, Jagannath P, Mehta AR, Mehta NG Elevated levels and fragmented nature of cellular fibronectin in the plasma of gastrointestinal and head and neck cancer patients. Clin Chim Acta 2006, 372:83-93.

6. Haglund C, Ylatupa S, Mertaniemi P, Partanen P: Cellular fibronectin concentration in the plasma of patients with malignant and benign diseases: a comparison with CA 19-9 and CEA. Br J Cancer 1997 76:777-783.

7. Torbenson M, Wang J, Choti M, Ashfaq R, Maitra A, Wilentz RE, Boitnott J: Hepatocellular carcinomas show abnormal expression of fibronectin protein. Mod Pathol 2002, 15:826-830.

8. Ylatupa S, Haglund C, Mertaniemi P, Vahtera E, Partanen P: Cellular fibronectin in serum and plasma: a potential new tumour marker? $\mathrm{Br} \mathrm{J}$ Cancer 1995, 71:578-582

9. Cho J, Mosher DF: Role of fibronectin assembly in platelet thrombus formation. J Thromb Haemost 2006, 4:1461-1469.

10. Mosher DF: Plasma fibronectin concentration: a risk factor for arterial thrombosis? Arterioscler Thromb Vasc Biol 2006, 26:1193-1195.

11. Orem C, Celik S, Orem A, Calapoglu M, Erdol C: Increased plasma fibronectin levels in patients with acute myocardial infarction complicated with left ventricular thrombus. Thromb Res 2002, 105:37-41.

12. Guinan P, Sobin LH, Algaba F, Badellino F, Kameyama S, MacLennan G, Novick A: TNM staging of renal cell carcinoma: Workgroup No. 3. Union International Contre le Cancer (UICC) and the American Joint Committee on Cancer (AJCC). Cancer 1997, 80(5):992-993.

13. Fuhrman SA, Lasky LC, Limas C: Prognostic significance of morphologic parameters in renal cell carcinoma. The American journal of surgical pathology 1982, 6(7):655-663.

14. Stenzl A, deKernion JB: Pathology, biology, and clinical staging of renal cell carcinoma. Seminars in oncology 1989, 16(1 Suppl 1):3-11.

15. Schmittgen TD, Livak KJ: Analyzing real-time PCR data by the comparative C(T) method. Nat Protoc 2008, 3:1101-1108.

16. Livak KJ, Schmittgen TD: Analysis of relative gene expression data using real-time quantitative PCR and the 2(-Delta Delta $C(T)$ ) Method. Methods 2001, 25:402-408.

17. Kampstra P: Beanplot: A Boxplot Alternative for Visual Comparison of Distributions. 2008 [http://www.cs.vu.nl/ pkampst/].

18. de la Fuente MT, Casanova B, Garcia-Gila M, Silva A, Garcia-Pardo A: Fibronectin interaction with alpha4beta1 integrin prevents apoptosis in $\mathrm{B}$ cell chronic lymphocytic leukemia: correlation with Bcl-2 and Bax. Leukemia 1999, 13:266-274.

19. Wolf M, El-Rifai W, Tarkkanen M, Kononen J, Serra M, Eriksen EF, Elomaa I, Kallioniemi A, Kallioniemi OP, Knuutila S: Novel findings in gene expression detected in human osteosarcoma by cDNA microarray. Cancer Genet Cytogenet 2000, 123:128-132 
20. Sallinen SL, Sallinen PK, Haapasalo HK, Helin HJ, Helen PT, Schraml P, Kallioniemi OP, Kononen J: Identification of differentially expressed genes in human gliomas by DNA microarray and tissue chip techniques. Cancer Res 2000, 60:6617-6622.

21. Chen M, Marinkovich MP, Jones JC, OToole EA, Li YY, Woodley DT: NC1 domain of type VII collagen binds to the beta3 chain of laminin 5 via a unique subdomain within the fibronectin-like repeats. J Invest Dermatol 1999, 112:177-183.

22. Takayasu H, Horie $\mathrm{H}$, Hiyama E, Matsunaga $T$, Hayashi $Y$, Watanabe $Y$, Suita S, Kaneko M, Sasaki F, Hashizume K, et al: Frequent deletions and mutations of the beta-catenin gene are associated with overexpression of cyclin D1 and fibronectin and poorly differentiated histology in childhood hepatoblastoma. Clin Cancer Res 2001, 7:901-908.

23. Tapper J, Kettunen E, El-Rifai W, Seppala M, Andersson LC, Knuutila S: Changes in gene expression during progression of ovarian carcinoma. Cancer Genet Cytogenet 2001, 128:1-6.

24. Schrader AJ, Rauer-Bruening S, Olbert PJ, Hegele A, Rustemeier J, Timmesfeld N, Varga Z, Hofmann R: Incidence and long-term prognosis of papillary renal cell carcinoma. J Cancer Res Clin Oncol 2009, 135:799-805.

25. Brenner W, Gross S, Steinbach F, Horn S, Hohenfellner R, Thuroff JW Differential inhibition of renal cancer cell invasion mediated by fibronectin, collagen IV and laminin. Cancer Lett 2000, 155:199-205.

26. Lohi J, Tani T, Leivo I, Linnala A, Kangas L, Burgeson RE, Lehto VP, Virtanen I: Expression of laminin in renal-cell carcinomas, renal-cell carcinoma cell lines and xenografts in nude mice. Int I Cancer 1996 68:364-371.

27. Murata J, Saiki I, Yoneda J, Azuma I: Differences in chemotaxis to fibronectin in weakly and highly metastatic tumor cells. Jpn J Cancer Res 1992, 83:1327-1333.

28. Patard JJ, Leray E, Rioux-Leclercq N, Cindolo L, Ficarra V, Zisman A, De La Taille A, Tostain J, Artibani W, Abbou CC, et al: Prognostic value of histologic subtypes in renal cell carcinoma: a multicenter experience. J Clin Oncol 2005, 23:2763-2771.

\section{Pre-publication history}

The pre-publication history for this paper can be accessed here: http://www.biomedcentral.com/1471-2407/10/503/prepub

doi:10.1186/1471-2407-10-503

Cite this article as: Waalkes et al:: Fibronectin 1 mRNA expression correlates with advanced disease in renal cancer. BMC Cancer 2010 10:503.

\section{Submit your next manuscript to BioMed Central and take full advantage of:}

- Convenient online submission

- Thorough peer review

- No space constraints or color figure charges

- Immediate publication on acceptance

- Inclusion in PubMed, CAS, Scopus and Google Scholar

- Research which is freely available for redistribution 